\title{
Assessing the damage of forests burnt in central Chile by relating index-derived differences to field data
}

\author{
M. A. Peña ${ }^{1 *}$ A. Bravo ${ }^{1}$, E. Fernández ${ }^{1}$ \\ ${ }^{1}$ Departamento de Geografía, Universidad Alberto Hurtado, Almirante Barroso 10, Santiago, Chile - mapena@ uahurtado.cl; \\ (aabravo, esfernan)@alumnos.uahurtado.cl
}

KEY WORDS: wildfires, spectral indices, composite burn index, Sentinel-2.

\begin{abstract}
:
To assess the damage produced by wildfires on forest ecosystems is a critical task for their subsequent management and ecological restoration. Satellite-based optical images provide reliable ex-ante and ex-post data about vegetation state, making them suitable for the aforementioned purpose. In this study we assessed the damage produced on two forested lands by the series of wildfires occurred in central Chile during summer 2017. Arithmetic differences from pre- and post-fire NDVI (normalized difference vegetation index), NDWI (normalized difference water index) and NBR (normalized burnt ratio) were retrieved from a Sentinel-2 image set embracing four near-anniversary summer dates: 2016 (ex-ante), 2017, 2018 and 2019 (ex-post). The nine index-derived differences resulting were correlated to CBI (composite burn index) data collected in the field during summer 2019, and a model constructed by a stepwise regression was formulated. Results show that planted forests exhibited a somewhat smaller biomass recovery than native ones, in part due to their post-fire clearing and preparation, deriving in a smaller tree cover. CBI poorly performed because its calculation includes low vegetation strata largely recovered at the time of the field data collection. However, when overstory field data were used alone correlations noticeably increased $(r=0,66-0,74)$. This was because during the field campaign this stratum was still appreciably damaged, thus better matching with the data provided by the indices-derived differences, intrinsically more representative of uppermost vegetation layers. The burn damage was mapped on both study areas employing the best performing regression model, based on NDWI2016-2019, NDWI2016-2017, NBR2016-2018 and $\mathrm{NBR}_{2016-2017}$ differences (adjusted $\mathrm{R}^{2}=0.72, p<0.005$, root mean square error $=0.38$ ). The use of approaches like this one in other areas of central Chile, where wildfires are increasing their frequency and intensity, might contribute to better lead post-fire management and restoration actions on their damaged forest ecosystems.
\end{abstract}

\section{INTRODUCTION}

Wildfires may produce severe disturbances on forest ecosystems, among these: biodiversity destruction, habitat fragmentation, soil erosion and sterilization, water and atmosphere degradation and carbon dioxide release (Chuvieco, 1999). Although most of the wildfires are caused by human actions, the temperature rising and the humidity diminishing trends, both influenced by the global climate change, have increased their frequency and intensity (Westerling et al. 2006; González et al., 2011). This especially occurs over regions subject to dry and hot summers, like those inserted on Mediterranean climates, where the fire's triad (fuel, climate and topography) is enhanced (Díaz-Delgado, 2000; González et al., 2011; Díaz-Hormazábal and González, 2016; Font et al., 2016).

To assess and monitoring the calcination severity and biomass recovery progression of a burnt forest ecosystem is a key task to orientate long- and short-term site-specific post-fire actions of management and ecological restoration. In this regard, satellitebased optical remote sensing stands out as a cost-efficient tool for capturing and analysing data sensitive to the effects produced by wildfires on any vegetation land cover. It provides a synoptic overview of vast calcined areas at frequent and regular time intervals (Gitas et al., 2012). The capabilities offered by optical images to retrieve vegetation state variables related to disturbances like wildfires is widely documented in the scientific literature, where subtractions between ex-ante and ex-post spectral vegetation indices have been routinely used as fire damage proxies (Chuvieco et al., 2002; Key and Benson, 2006; Escuin et al., 2008; Sever et al., 2012, Ryu et al., 2018). These indices result from arithmetically combining spectral samples or bands sensitive to several physical-chemical vegetation parameters.

The ability of an ecosystem to regenerate and to achieve its primal condition, i.e., resilience capability, will depend on the calcination severity or intensity of its biomass, as well as its response to ecosystem variables like seedling recruitment, resprouting, alien and native species colonization, among others (Keeley, 2009; Chen et al., 2011). In this sense, it should be noted that values retrieved from index-derived differences are more closely sensitive to the bulk amount of calcined or recovered biomass, and not necessarily to the reestablishment of other ecological attributes of the burnt ecosystem, such as structure and composition (Bastos et al., 2011; Peña and Ulloa, 2017). In spite of this, to relate these values to quantitative or qualitative field data of biomass calcination or recovery contributes to understand the response of several of those variables to fire damage (Key and Benson, 2006; De Santis and Chuvieco, 2009).

In this study vegetation spectral indices were related to field data in order to assess the impact of fire on planted and native forest land covers. Two of the largest forested lands burnt during the series of wildfires affecting central Chile on the 2017 summer, were considered as study areas. Biomass burn severity of the target forests along two years after the wildfires was inferred by the ex-post to ex-ante subtraction of three wellknown vegetation spectral indices retrieved from Sentinel-2 images. Thereafter, CBI (composite burn index) data collected in the field during summer 2019 were employed to model burn severity using the index-derived differences as predictors in a stepwise regression analysis. 


\section{MATERIALS AND METHODS}

\subsection{Study area}

Two areas burnt during summer 2017 in central Chile, known as Nilahue-Barahona and Las Máquinas, were targeted in this study. The former is located in Region VI (between latitudes $34^{\circ} 05^{\prime}$ y $34^{\circ} 75^{\prime} \mathrm{S}$ ) comprising an area of $490 \mathrm{~km}^{2}$, and the latter is in Region VII (between latitudes $35^{\circ} 05^{\prime}$ y $35^{\circ} 51^{\prime}$ S) reaching an area of $2163 \mathrm{~km}^{2}$. Both are covered by similar forest formations, distributed along the Coastal mountain, roughly at 400 m.a.s.l., and subject to a predominantly Mediterranean climate. In Nilahue-Barahona, planted and native forests comprise 44.86 and $55.14 \%$ respectively, of the whole forest lands, whereas in Las Máquinas these percentages correspond to 87.7 and 12.72. On both areas planted forests comprise Radiata pine (Pinus radiata D. Don) monocultures mostly, while native forests mostly correspond to sclerophyll formations with some minor variations bewteen their compositions.

\subsection{Materials}

A set of four Sentinel-2 images comprising pre- and post-fire near anniversary dates of each study area (Table 1) was downloaded from the ESA (European Spatial Agency) online service https://scihub.copernicus.eu/.

\begin{tabular}{|c|c|c|}
\hline Study area & \multicolumn{2}{|c|}{ Image acquisition date } \\
\cline { 2 - 3 } & Pre-fire & Post-fire \\
\hline Nilahue- & December 20, 2016 & February 18, 2017 \\
Barahona & & \\
& & February 18, 2018 \\
& & February 23, 2019 \\
Las & January 19, 2017 & March 20, 2017 \\
Máquinas & & March 15, 2018 \\
& & March 20, 2019 \\
\hline
\end{tabular}

Table 1. Acquisition dates of the Sentinel-2 images for each study area.

Sentinel-2 images are acquired by an optical pushbroom scanner (MSI, Multispectral Instrument) comprising 13 bands across visible and infrared wavelengths of the spectrum. The product used (L2A) records at-surface reflectances orhorectified in UTM (Universal Transverse of Mercator) projection, datum WGS84 (World Geodetic System 1984). The bands were spatially resampled to the finest Sentinel-2 pixel $(10 \mathrm{~m})$ by the nearest neighbour method.

\subsection{Methods}

Three commonly used vegetation spectral indices were retrieved from each image (Table 2).

\begin{tabular}{|c|c|c|c|}
\hline Index & Notation & Formula & Reference \\
\hline $\begin{array}{c}\text { Normalized } \\
\text { difference }\end{array}$ & NDVI & $(\rho 842-\rho 665) /$ & Rouse et al., \\
vegetation & & $(\rho 842+\rho 665)$ & $(1973)$ \\
index & & & \\
$\begin{array}{c}\text { Normalized } \\
\text { difference }\end{array}$ & NDWI & $(\rho 842-\rho 1610)$ & Hunt and Rock \\
water index & & $/(\rho 842+\rho 1610)$ & $(1989)$ \\
$\begin{array}{c}\text { Normalized } \\
\text { burn ratio }\end{array}$ & NBR & $(\rho 842-\rho 2190)$ & Key and Benson \\
\hline
\end{tabular}

Table 2. Vegetation spectral indices used in this study.
Each post-fire index was subtracted to its corresponding pre-fire index to obtain a difference depicting the burn severity of the targeted forests for that period. A field campaign carried out in summer 2019, enabled to measure that variable on 31 forest plots exhibiting a homogenous condition within a radius of 20 $\mathrm{m}$ (twice the image pixel size used). They were opportunistically scattered across both type of forests: planted $(n=22)$ and native $(n=9)$ of the Nilahue-Barahona $(n=13)$ and Las Máquinas $(n=18)$ study areas. The measurement method employed was the widely known CBI, an index that averages the magnitude of fire damage observed on the understory (including substrate) and overstory strata of a given forest plot, using a continuous scale from 0 (no calcination) to 3 (completely calcined) (for more methodological details see Key and Benson, 2006).

The nine index-derived differences resulting were correlated to three field data sets: the measurements made on understory and overstory strata separately, and the CBI integrating both. A stepwise regression (i.e., combining backward and forward variables selection) using the field data set yielding the highest correlation as dependent variable and the index-derived differences as predictors was performed. The predictors were selected by the adjusted determination coefficient $\left(\mathrm{R}^{2}\right)$ and the model's performance was further assessed by the RMSE (root mean square error) resulting from a 100 times repeated 5-fold cross-validation.

\section{RESULTS}

As it could be expected, on both study areas index-derived differences were the widest for those including the first post-fire image date, being reflected in their largest mean differences (Figures 1 and 2). These averages progressively diminished throughout the index-derived differences including the remaining post-fire image dates. In general, index-based differences exhibited similar temporal patterns, with planted forests consistently showing larger mean index-derived differences than native or mixed ones.

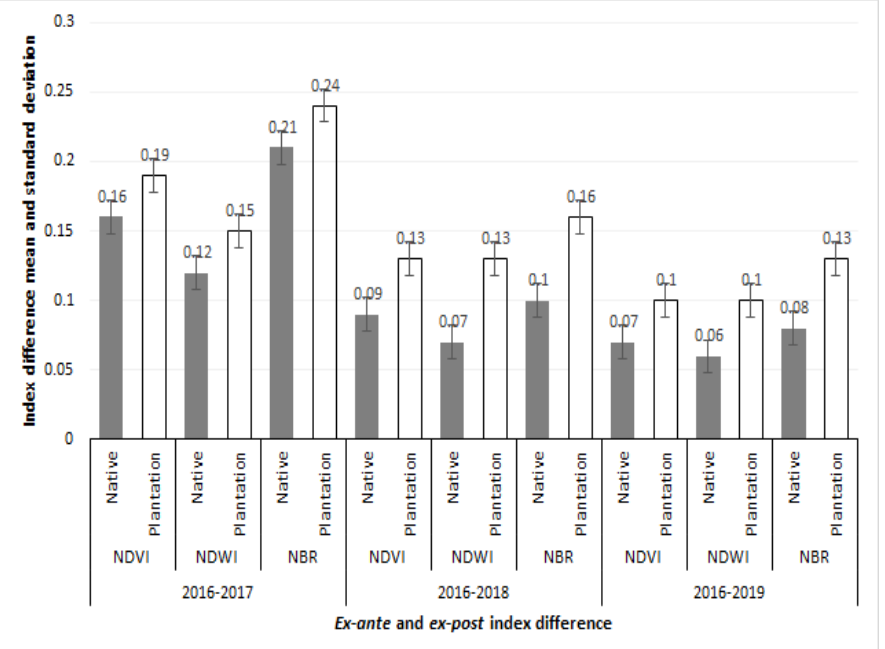

Figure 1. Mean and standard deviation of the index-derived differences (ex-ante minus ex-post image dates) for NilahueBarahona's forest land covers. 


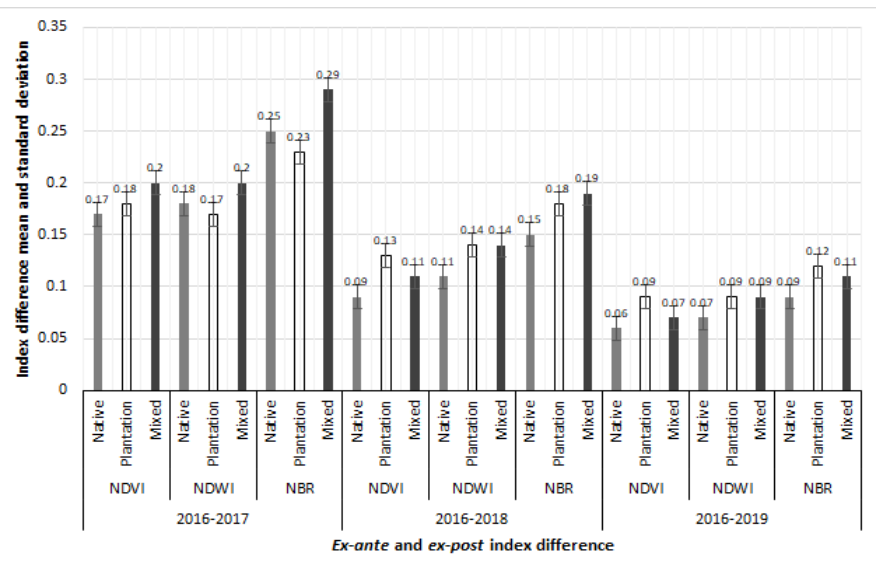

Figure 2. Mean and standard deviation of the index-derived differences (ex-ante minus ex-post image dates) for Las Maquinas' forest land covers.

Correlation coefficients retrieved between field and remote sensing data showed different behaviours, mainly depending on the field data set employed (Table 3). For CBI (i.e., upper and lower tree canopy strata measurements), they were low ( $r=$ 0.22-0.39), but when overstory data were used alone, correlations were strengthened $(66 \%$ of the them $\geq 0.66)$. For understory instead, correlations were very low or almost inexistent. Similar behaviours were observed in the correlations when data were partitioned according to forest type (data not shown). For the best correlated data set (i.e., using overstory), it was observed that NDWI and NBR yielded the highest correlations, especially for the index-derived differences using the second and third post-fire image dates $(r=0.66-0.74)$.

\begin{tabular}{|c|c|c|c|c|}
\hline Image & Forest & \multicolumn{3}{|c|}{$r$} \\
\cline { 3 - 5 } subtraction & stratum & NDVI & NDWI & NBR \\
\hline \multirow{3}{*}{$2016-2017$} & Overstory & 0.43 & 0.32 & 0.28 \\
& Understory & 0.08 & 0.06 & 0.17 \\
& CBI (total) & 0.31 & 0.24 & 0.26 \\
& Overstory & 0.66 & 0.71 & 0.66 \\
$2016-2018$ & Understory & -0.08 & -0.18 & 0.11 \\
& CBI (total) & 0.33 & 0.31 & 0.34 \\
& Overstory & 0.35 & 0.7 & 0.74 \\
$2016-2019$ & Understory & 0 & -0.2 & -0.13 \\
& CBI (total) & 0.24 & 0.32 & 0.39 \\
\hline
\end{tabular}

Table 3. Correlation coefficients $(r)$ for CBI and each of the

forest strata composing it, according to index-derived difference.

A stepwise regression revealed that the most robust linear model of forest fire damage for the overstory stratum of both study areas should consider $\mathrm{NDWI}_{2016-2019}, \mathrm{NDWI}_{2016-2017}$, $\mathrm{NBR}_{2016-2018}$ and $\mathrm{NBR}_{2016-2017}$ as predictors (adjusted $\mathrm{R}^{2}=0.72$, $p<0.005, \operatorname{RMSE}=0.38)$.

\section{DISCUSSION AND CONCLUSIONS}

Index-derived differences revealed that forests of both study areas experienced a progressive biomass recovery two years after wildfires. However, regardless the spectral index, slowest recoveries were found in the case of planted forests. On one hand, this is likely due to the relatively high fire severity that the targeted forest plantations may reach, as a result of the high fuel load of their dominant species (Radiata pine and Eucalyptus spp.). On the other hand, sclerophyll species tend to exhibit fast post-fire recovery because of a morphology and physiology fitted to thermal and water stresses (Gómez and Hahn, 2017). Aside from that, post-fire regrowth of scleropyll formations not only relies on seeding, as for Radiata pine plantations, but also resprouting (Reyes and Casal, 2000). This regrowth is faster for herbs, shrubs and small trees comprising their understory, a canopy layer often inexistent in monostructural plantations like those targeted (Key and Benson, 2006). Finally yet importantly, we observed extensive post-fire clearing on many burnt plantations during the field campaign, exhibiting bare soils under preparation. This situation contributed to post-fire index dates exhibiting low values and therefore, relatively large differences when subtracting to their corresponding ex-ante date. Such a values erroneously were part of scarcely recovered or severely burnt forest land covers (i.e., false positives).

Spectral indices had a similar performance, indicating that even when they are sensitive to different physical-chemical vegetation parameters (i.e., vigor and turgor) a significant autocorrelation may arise between them, as previous studies have pointed out (Chen et al., 2011; Peña and Ulloa, 2017). NDWI- and NBR-based differences yielded the highest correlations and predictive power, especially using the second and third post-fire image dates. These indices are constructed with bands belonging to the SWIR region, which have had a good performance in several forest-related studies (Frolking et al., 2009; Banskota et al., 2014), particularly those orientated to wildfire damage assessment by benchmarking different spectral indices (Chuvieco and Kasischke, 2007, Escuín et al., 2008; Chen et al., 2011), The usefulness of these bands relies on their relatively minor sensitivity to the noise due the atmosphere scattering and their high sensitivity to scarcely vegetated or bare soils (Banskota et al., 2014). The lower correlations yielded for index-derived differences calculated immediately after the fire extinction (using the 2017 image date) were as expected, as those differences should more weakly relate to field data collected two years later, when forests were recovered to some extent.

The poor performance of $\mathrm{CBI}$ is also explained by the aforementioned temporal mismatch between both, field and remote sensing data sets. As it could be expected, understory was largely recovered two years after wildfire, when field campaign was made, thus introducing lower burn severity values to CBI. Meanwhile, overstory exhibited more damaged canopies at that time, especially on its taller and bigger trees. Since images better depict the uppermost vegetation strata, overstory field measurements will stronger correlate to their corresponding pixel-derived data (De Santis and Chuvieco, 2009). Consequently, we obtained higher correlations and more predictive power when using this data set alone. This finding warns about using CBI in its original form when pretending to relate it to earlier remote sensing data, being recommendable to consider only the overstory stratum.

Future studies should improve the methods and further explore the findings exposed here by expanding the observations to other wildfires of central Chile, affecting different forest formations under different site conditions. Moreover, they should test other regressions and validation approaches (e.g. regularized linear functions and spatial cross-validations), which have shown more robust predictability for vegetation ecology studies using large set of predictors and subject to spatial autocorrelation (Zandler et al., 2015; Schratz et al., 2019). This might contribute to formulate more accurate models 
of fire damage for the different Chilean biomes. Such a task assumes a special meaning in the Chilean forestry context, where wildfires are occurring more often and with increasing intensity (Peña-Fernández and Valenzuela-Palma, 2004).

\section{REFERENCES}

Banskota, A., Kayastha, N., Falkowski, M.J., Wulder, M.A., Froese, R.E., White, J.C. 2014. Forest monitoring using Landsat time series data: A review, Canadian Journal of Remote Sensing, 40(5): 362-384.

Bastos, A., Gouveia, C.M., DaCamara, C.C., Trigo, R.M., 2011: Modelling post-fire vegetation recovery in Portugal. Biogeosciences, 8: 3593-3607.

Chen, X., Vogelmann, J.E., Rollins, M., Ohlen, D., Key, C.H., Yang, L., Huang, C., Shi, H., 2011: Detecting post-fire burn severity and vegetation recovery using multitemporal remote sensing spectral indices and field-collected composite burn index data in a ponderosa pine forest, International Journal of Remote Sensing, 32(23): 7905-7927.

Chuvieco, E., 1999: Remote sensing of large wildfires: In the European Mediterranean basin. Springer, Berlín.

Chuvieco, E., Kasischke, E.S., 2007: Remote sensing information for fire management and fire effects assessment, Journal of Geophysical Research, 112, G01S90.

Chuvieco, E., Martín, M.P., Palacios, A., 2002: Assessment of different spectral indices in the red-near-infrared spectral domain for burned land discrimination. International Journal of Remote Sensing, 23: 5103-5110.

De Santis, A., Chuvieco, E., 2009: GeoCBI: A modified version of the Composite Burn Index for the initial assessment of the short-term burn severity from remotely sensed data. Remote Sensing of Environment, 113(3): 554-562.

Díaz-Delgado, R., 2000. Caracterización por medio teledetección del régimen de incendios forestales en Cataluña (período 1975 - 98) y su influencia en los procesos de regeneración. Tesis Doctoral, Universitat Autònoma de Barcelona, España.

Díaz-HormazábaL, I., González, M.E., 2016: Análisis espaciotemporal de incendios forestales en la región del Maule, Chile. Bosque, 37(1): 147-158.

Escuín, S., Navarro, R., Fernández, P., 2008: Fire severity assessment by using NBR (normalized burn ratio) and NDVI (normalized difference vegetation index) derived from Landsat TM/ETM images. International Journal of Remote Sensing, 29: 1053-1073.

Font, M., Serra, M., Borràs, M., Vilalta, O., Plana, E., 2016. El fuego y los incendios forestales en el Mediterráneo; la historia de una relación entre bosques y sociedad. Cinco mitos y realidades para saber más. Ediciones CTFC, Cataluña, España.

Frolking, S., Palace, M.W., Clark, D.B., Chambers, J.Q., Shugart, H.H., Hurtt, G.C. 2009. Forest disturbance and recovery: A general review in the context of spaceborne remote sensing of impacts on aboveground biomass and canopy structure. Journal of Geophysical Research, 114, G00E02.
Gitas, I., Mitri, G., Veraverbeke, S., Polychronaki, A., 2012. Advances in Remote Sensing of Post-Fire Vegetation Recovery Monitoring - A Review. In L. Fatoyinbo (Ed.), Remote sensing of biomass: Principles and applications. IntechOpen Limited, London, United Kingdom.

González, M.E., Lara, A., Urrutia, R., Bosnich, J., 2011: Dowman, I., 2008: Cambio climático y su impacto potencial en la ocurrencia de incendios forestales en la zona centro-sur de Chile (33 $-42^{\circ}$ S). Bosque, 32(3): 215-219.

Hunt, E.R., Rock, B.N., Nobel, P.S. 1987: Measurement of leaf relative water content by infrared reflectance. Remote Sensing of Environment, 22: 429-435.

Keeley, J.E., 2009: Fire intensity, fire severity and burn severity: a brief review and suggested usage. International Journal of Wildland Fire, 18: 116-126.

Key, C.H., Benson, N.C., 2006. Landscape Assessment (LA): Sampling and analysis methods. In D.C. Lutes, R.E. Keane, J.F. Caratti, C.H. Key, N.C. Benson, S. Sutherland, L.J. Gangi (Eds.), FIREMON: Fire effects monitoring and inventory system. Ogden, UT: USDA Forest Service, Rocky Mountain Research Station, Gen. Tech. Rep.

Peña-Fernández, E., Valenzuela-Palma, L., 2004. Incremento de los incendios forestales en bosques naturales y plantaciones forestales en Chile. In Memorias del Segundo Simposio Internacional sobre Politicas, Planificación y Economía de los Programas de Protección contra Incendios Forestales. 19-22 Abril, 2004, Córdoba, España, pp. 595-612.

Peña, M., Ulloa, J., 2017: Mapeo de la recuperación de la vegetación quemada mediante la clasificación de índices espectrales pre- y post-incendio. Revista de Teledetección, 50: $37-48$

Rouse, J.W., Haas, R.H., Schell, J.A., Deering, D.W. 1973: Monitoring vegetation systems in the Great Plains with ERTS In $3^{r d}$ ERTS Symposium, NASA SP-351 I, pp. 309-317.

Ryu, J.-H., Han, K.-S., Hong, S., Park, N.-W., Lee, Y.-W., Cho, J., 2018: Satellite-based evaluation of the post-fire recovery process from the worst forest fire case in South Korea. Remote Sensing, 10: 918

Sever, L., Leach, J., Bren, L., 2012: Remote sensing of post-fire vegetation recovery; a study using Landsat 5 TM imagery and NDVI in North-East Victoria. Journal of Spatial Science, 57(2): 175-191.

Westerling A.L., Hidalgo, H.G., Cayan, D.R., Swetnam, T.W. 2006. Warming and earlier spring increase western U.S. forest wildfire activity. Science, 313(5789): 940-943. 